EXPERIMENTAL STUDY

\title{
Follistatin-related gene expression, but not follistatin expression, is decreased in human endometrial adenocarcinoma
}

Pasquapina Ciarmela, Pasquale Florio, Matthildur Sigurðardóttir, Paolo Toti ${ }^{1}$, Veronique Maguer-Satta ${ }^{2}$, Ruth Rimokh ${ }^{2}$, Aldo Altomare, Piero Tosi ${ }^{1}$ and Felice Petraglia

Chair of Obstetrics and Gynecology, Department of Pediatrics, Obstetrics and Reproductive Medicine, and ${ }^{1}$ Department of Human Pathology and Oncology, University of Siena, Siena, Italy, and ${ }^{2}$ INSERM U453, Centre Leon Berard, 69373 Lyon, France

(Correspondence should be addressed to F Petraglia, Chair of Obstetrics and Gynecology, Department of Pediatrics, Obstetrics and Reproductive Medicine, University of Siena, Policlinico 'Le Scotte', viale Bracci, 53100 Siena, Italy; Email: petraglia@unisi.it)

P Ciarmela and P Florio contributed equally to this work

\begin{abstract}
Objective: Activin A is a multifunctional growth and cell differentiation factor produced by normal endometrium, and secreted in high amounts by endometrial adenocarcinoma. In the present study we evaluated the expression of two inhibitory activin A ligands, follistatin and follistatin-related gene (FLRG), in endometrial adenocarcinoma and in age-matched healthy human endometrium. Design and methods: Atropic menopausal $(n=13)$ and tumoral $(n=9$ adenocarcinoma) tissues were processed to evaluate mRNA expression levels (by semiquantitative RT-PCR) and peptide localization (by immunohistochemistry). Differences were evaluated by the unpaired $t$-test and assumed to be statistically significant when $P<0.05$.

Results: Both control and tumoral endometrial samples express and localize follistatin and FLRG. However, whereas follistatin mRNA expression did not differ significantly, FLRG was significantly lower in endometrial adenocarcinoma than in healthy endometrial specimens $(P<0.0001)$. With respect to the localization of proteins, follistatin was immunolocalized in endometrial epithelial and vascular cells both in tumoral and healthy endometrium without any significant difference in intensity. Nuclear and cytoplasmic FLRG immunolocalization was seen in glands, and only nuclear immunolocalization was found in stroma and vessels of healthy endometrium. FLRG was weakly immunostained in endometrial adenocarcinoma.

Conclusions: Whilst follistatin expression is unchanged, FLRG is down-regulated in endometrial carcinoma. As activin A is a differentiation factor of human endometrium, the present findings support an imbalance between increased activin A and decreased FLRG expression in endometrial cancer, so that the failure of the activin A pathway through FLRG may be pivotal in endometrial tumorigenesis.
\end{abstract}

European Journal of Endocrinology 151 251-257

\section{Introduction}

Activin $\mathrm{A}$ is a dimeric protein (composed of two $\beta \mathrm{A}$ subunits) member of the transforming growth factor- $\beta$ superfamily, a group of structurally similar but functionally diverse growth factors (1). Despite being initially isolated from porcine ovarian follicular fluid, activin A subunits have subsequently been found in a host of organs where, acting on its own receptors (ActRs), it exerts a wide variety of effects depending upon the cell system examined; however, it acts mainly as a local modulator of cell growth and differentiation (2).

Follistatin is a monomeric glycoprotein that, despite being structurally unrelated to activins, is able to bind activin A with high affinity, preventing interaction to its own receptors, and thus neutralizing its biological effects (2-9). Recently, a new protein that shares the characteristic 10-cysteine structures of follistatin domains was cloned from a B cell leukemia line based on its overexpression in response to a chromosomal translocation (10). Referred to as follistatin-related gene (FLRG) on the basis of the striking sequence homology with follistatin (11), it also shares a similar Nterminal domain with follistatin, a region that is crucial for the binding to activin (12) and, like follistatin, it binds strongly to activin $(11,13,14)$.

Activin A, follistatin (15-22) and FLRG (23) are expressed by human endometrium, and human 
endometrial cells are also able to secrete activin A and follistatin in the uterine washing fluid throughout the menstrual cycle (22). Furthermore, activin A mRNA and protein expression have been reported to be significantly increased in endometrial adenocarcinoma (21), as well as in the serum and uterine washing fluid of patients affected by endometrial cancer (15).

Since no data are available on follistatin and FLRG in endometrial cancer, in the present study we investigated the mRNA expression levels and peptides distribution in endometrial adenocarcinoma compared with healthy age-matched controls.

\section{Materials and methods}

Informed written consent was obtained from all patients prior to inclusion in the study, for which approval from the local Human Investigation Committee was obtained.

Two groups of women were studied. The first group consisted of post-menopausal women with endometrial adenocarcinoma ( $n=9$; age range $61-79$ years), who enrolled at the time of diagnosis, and had not taken any hormonal replacement therapy in their clinical history. Pathological diagnosis was carried out on hysterectomy specimens and, according to the criteria of the International Federation of Gynecology and Obstetrics, they were classified as well differentiated (grade 1; $n=6$ endometrioid adenocarcinoma, of whom $n=1$ had squamous differentiation and $n=1$ clear cell carcinoma) and poorly differentiated (grade $3 ; n=3$ endometrioid adenocarcinoma) (Table 1). The second group consisted of atropic post-menopausal women ( $n=13$; age range $64-78$ years), who underwent hysterectomy for uterine prolapse (controls), and served as age-matched controls. In the clinical history of these subjects, the absence of infections or neoplastic diseases, and of any estrogen and/or progestin pretreatment were the exclusion criteria.

All specimens collected were, in part, fixed by immersion in $10 \%$ buffered formalin for the immunohistochemistry study, and, in part, immediately submerged in an RNA stabilization reagent (RNAlater, QIAGEN, Milan, Italy) for the extraction of total RNA, in order to perform qualitative and semi-quantitative reverse transcriptase-polymerase chain reaction (RT-PCR).

\section{RNA preparation}

Samples were disrupted and homogenized using Mixer Mill MM 300 (QIAGEN) and total RNA was extracted with RNeasy Protect Mini Kit and treated with RNase-free DNase according to the manufacturer's instructions (QIAGEN). Total RNA was quantified by UV absorption at $260 \mathrm{~nm}$.

\section{RT-RCR}

The reverse transcription reaction was carried out using a Thermoscript RT-PCR system purchased from Invitrogen (Milan, Italy). First-strand cDNA was synthesized from $1 \mu \mathrm{g}$ total RNA. After denaturing template RNA, oligo $\mathrm{d}(\mathrm{T})$ primers, and $10 \mathrm{mmol} / \mathrm{l} \mathrm{dNTP}$ mix for $5 \mathrm{~min}$ at $65^{\circ} \mathrm{C}, 15 \mathrm{U}$ RT were added in the presence of cDNA synthesis buffer $(250 \mathrm{mmol} / \mathrm{l}$ Tris acetate $(\mathrm{pH} 8.4), 375 \mathrm{mmol} / \mathrm{l}$ potassium acetate, $40 \mathrm{mmol} / \mathrm{l}$ stabilizer), $40 \mathrm{U}$ RNase inhibitor, $0.1 \mathrm{~mol} / \mathrm{l}$ dithiothreitol, and diethyl pyrocarbonate (DEPC)-treated water to make $20 \mu \mathrm{l}$. The mixture was incubated at $50{ }^{\circ} \mathrm{C}$ for $45 \mathrm{~min}$, then heated to $85^{\circ} \mathrm{C}$ for $5 \mathrm{~min}$ to stop the reaction and stored at $-20^{\circ} \mathrm{C}$. Two microliters of the product were used for the PCR reaction.

Table 1 Individual intensity of follistatin and FLRG immunostaining of atropic (controls) and endometrioid cancer tissues scored on a subjective scale ranging from - (no staining) to ++++ (maximal staining) by three independent assessors.

\begin{tabular}{|c|c|c|c|c|c|c|c|c|c|}
\hline \multicolumn{5}{|c|}{ Follistatin } & \multicolumn{5}{|c|}{ FLRG } \\
\hline Controls & $\begin{array}{l}\text { Staining } \\
\text { intensity }\end{array}$ & $\begin{array}{c}\text { Endometrial } \\
\text { cancer }\end{array}$ & $\begin{array}{l}\text { Staining } \\
\text { intensity }\end{array}$ & Grade/stage & Controls & $\begin{array}{l}\text { Staining } \\
\text { intensity }\end{array}$ & $\begin{array}{c}\text { Endometrial } \\
\text { cancer }\end{array}$ & $\begin{array}{l}\text { Staining } \\
\text { intensity }\end{array}$ & Grade/stage \\
\hline$\# 1$ & ++ & $\# 1$ & + & $1 / \mathrm{IB}$ & $\# 1$ & ++++ & $\# 1$ & + & $1 / \mathrm{IB}$ \\
\hline \#2 & ++ & \#2 & ++ & $1 / \mathrm{IB}$ & \#2 & +++ & \#2 & ++ & $1 / \mathrm{IB}$ \\
\hline \#3 & ++ & \#3 & ++ & $1 / I C$ & \#3 & +++ & \#3 & + & $1 / I C$ \\
\hline$\# 4$ & + & $\# 4$ & ++ & $1 / \mathrm{IB}$ & \#4 & +++ & $\# 4$ & + & $1 / \mathrm{IB}$ \\
\hline \#5 & ++ & $\# 5^{\star}$ & ++ & $1 / I C$ & \#5 & +++ & $\# 5^{\star}$ & ++ & $1 / I C$ \\
\hline \#6 & ++ & $\# 6^{\star \star}$ & + & $1 / I C$ & \#6 & ++++ & $\# 6^{\star \star}$ & ++ & $1 / I C$ \\
\hline \#7 & ++ & \#7 & ++ & $3 / 1 B$ & $\# 7$ & +++ & \#7 & ++ & $3 / I B$ \\
\hline \#8 & + & \#8 & + & $3 / 1 B$ & \#8 & +++ & \#8 & ++ & $3 / 1 B$ \\
\hline$\# 9$ & ++ & \#9 & + & $3 / \mathrm{IB}$ & \#9 & ++ & \#9 & + & $3 / \mathrm{IB}$ \\
\hline \#10 & + & & & & \#10 & +++ & & & \\
\hline$\# 11$ & + & & & & $\# 11$ & +++ & & & \\
\hline \#12 & ++ & & & & \#12 & ++++ & & & \\
\hline$\# 13$ & + & & & & $\# 13$ & +++ & & & \\
\hline
\end{tabular}

* With squamous differentiation; **Clear cell endometrioid adenocarcinoma. 
The polymerase chain reaction was performed under the following conditions: $20 \mathrm{mmol} / \mathrm{l}$ Tris $-\mathrm{HCl}, \mathrm{pH} 8.4$, $50 \mathrm{mmol} / \mathrm{l} \mathrm{KCl}, 1.5 \mathrm{mmol} / \mathrm{l} \mathrm{MgCl}_{2}, 0.25 \mathrm{mmol} / \mathrm{l}$ of each dNTP, $1 \mathrm{U}$ Taq DNA polymerase, recombinant $0.4 \mu \mathrm{mol} / \mathrm{l}$ (final concentration) primers (Invitrogen) in $50 \mu \mathrm{l}$ of total volume. The specific primers used to amplify cDNA fragments corresponding to follistatin (Genebank accession no. J03771), common to both splice variants, FLRG (Genebank accession no. U76702) and hypoxanthine phosphoribosyltransferase (HPRT (Genebank accession no. M26434), used as a housekeeping gene (24)), were: 5'TGCCACCTGAGAAA-

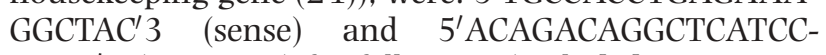
$\mathrm{GACT}^{\prime} 3$ (antisense) for follistatin (included intron size: 904 bp; expected size: 201 bp); 5'ACCTGAGCGTCATGT$\mathrm{ACCG}^{\prime} 3$ (sense) and 5'TGTGGCACGAGGAGATGTAG'3 (antisense) for FLRG (included intron size: $792 \mathrm{bp}$; expected size: $198 \mathrm{bp}$ ); 5'TGAAGCTGCAGACACT$\mathrm{CAGG}^{\prime} 3$ (sense) and 5'CTCTCCCAACACCATCACCT'3 (antisense) for HPRT (included intron size: 270; expected size: $99 \mathrm{bp}$ ). The primers for follistatin and FLRG, as well as those for HPRT, both span large introns, reducing the likelihood of possible genomic material amplification thus serving to detect possible genomic contamination. Computer analysis performed to compare the synthesized oligomers with the human sequences in the gene database of the National Center for Biotechnology (NBCI), using BLAST (25), revealed no significant homology with other genes.

PCRs for follistatin consisted of 32 thermal cycles of $94^{\circ} \mathrm{C}$ for $30 \mathrm{~s}, 50^{\circ} \mathrm{C}$ for $1 \mathrm{~min}$ and $72^{\circ} \mathrm{C}$ for $20 \mathrm{~s}$. For FLRG, 36 thermal cycles of $94^{\circ} \mathrm{C}$ for $30 \mathrm{~s}, 55^{\circ} \mathrm{C}$ for $1 \mathrm{~min}$ and $72^{\circ} \mathrm{C}$ for $20 \mathrm{~s}$ were used. The HPRT program was 30 thermal cycles of $94^{\circ} \mathrm{C}$ for $30 \mathrm{~s}, 52^{\circ} \mathrm{C}$ for $30 \mathrm{~s}$ and $72{ }^{\circ} \mathrm{C}$ for $12 \mathrm{~s}$. The first cycle was preceeded by denaturation at $94^{\circ} \mathrm{C}$ for $2 \mathrm{~min}$, and the last cycle was followed by an extension at $72^{\circ} \mathrm{C}$ for $5 \mathrm{~min}$. The number of PCR cycles was established after testing a range of 20-40 to ensure that the amount of DNA product remained in the logarithmic range of the amplification curve, so that useful semi-quantified comparisons could be made. For each reaction, the reverse transcriptase was omitted in the amplification mixture during the RT-PCR so as to rule out genomic contamination, and was used as a negative control.

Amplification products $(15 \mu \mathrm{l})$ were visualized on a $2 \%$ agarose gel stained with ethidium bromide and photographed under UV light. The expected bands were analyzed by densitometry and data were expressed as the ratio between FLRG or follistatin CDNAs and the corresponding HPRT cDNA.

\section{Immunohistochemistry}

Immunohistochemistry was carried out on $5 \mu$ m-thick sections obtained by paraffin-embedded samples, mounted on electrostatically charged slides, and dried overnight at $37^{\circ} \mathrm{C}$. Sections were dewaxed, rehydrated and washed in Tris-buffered saline (TBS; $20 \mathrm{mmol} / \mathrm{l}$ Tris- $\mathrm{HCl}, 150 \mathrm{mmol} / \mathrm{l} \mathrm{NaCl}(\mathrm{pH}$ 7.6)). Tissue sections were immersed in ethylenediamine tetraacetic acid (EDTA), and heated in a microwave oven two times for $5 \mathrm{~min}$ at $750 \mathrm{~W}(\mathrm{pH} 8)$ and rinsed in 3\% hydrogen peroxide to block endogenous peroxidase. Slides were incubated overnight at room temperature with primary antibody.

The antiserum used for FLRG was a polyclonal rabbit antibody (1:500), whose specificity and technical characteristics have been described previously (14). The antiserum used for follistatin was a polyclonal rabbit antibody (1:1000) provided by W Vale (Salk Institute, La Jolla, CA, USA) (26). Harris hematoxylin was used for nuclear counterstaining. A positive reaction was characterized by the presence of granular brown staining in the cytoplasm.

Negative controls consisted of sections where the primary antibody was replaced by non-immune serum and by using the antibodies pre-adsorbed with the blocking peptide (R\&D System, Milan, Italy).

\section{Assessment of staining}

The individual intensity of immunostaining of a tissue section was scored on a subjective scale of 0 (no staining) to 4 (maximal staining) by three independent assessors.

\section{Statistical analysis}

The statistical significance of differences between groups was evaluated by the unpaired $t$-test, and significance was assumed when $P<0.05$.

\section{Results}

\section{mRNA follistatin and FLRG expression}

Total RNA extracted from endometrium was analyzed by RT-PCR. Bands corresponding in size to follistatin (201 bp) and FLRG (198 bp) products were obtained and no amplified fragment caused by DNA contamination was detected in any experiment (data not shown).

As shown graphically in Fig. 1, follistatin mRNA expression did not differ between healthy subjects and tumoral patients, whereas the relative abundance of FLRG mRNA with respect to HPRT was significantly decreased in endometrial adenocarcinoma $(P<0.0001)$.

\section{Localization of follistatin peptide}

Post-menopausal endometrial glands, stromal and endothelial cells were positively stained by follistatin (Fig. 2F and 2G). Follistatin immunostaining was also found in endometrial adenocarcinoma cells (glands and stroma), intramyometrial and intratumoral 
neoformed vessels, smooth muscle cells of the media in muscular arteries, and in endothelial cells of arteries, veins and capillaries (Fig. 2A to 2E). No significant difference in stain intensity was observed between healthy and tumoral endometrium (Table 1).

\section{Localization of FLRG peptide}

In normal post-menopausal endometrium, glandular epithelial cells were strongly and consistently immunoreactive for FLRG, both in the cytoplasm and the nucleus, while in stromal cells immunoreactivity was restricted to the nucleus. Cytoplasmic and nuclear FLRG staining was also found in both endothelial and smooth muscle cells of the vessels (Fig. 3F).

Neoplastic glands (Fig. 3A to 3E) featured positive immunoreactivity both in the nucleus and the cytoplasm, but the stain was very weak when compared
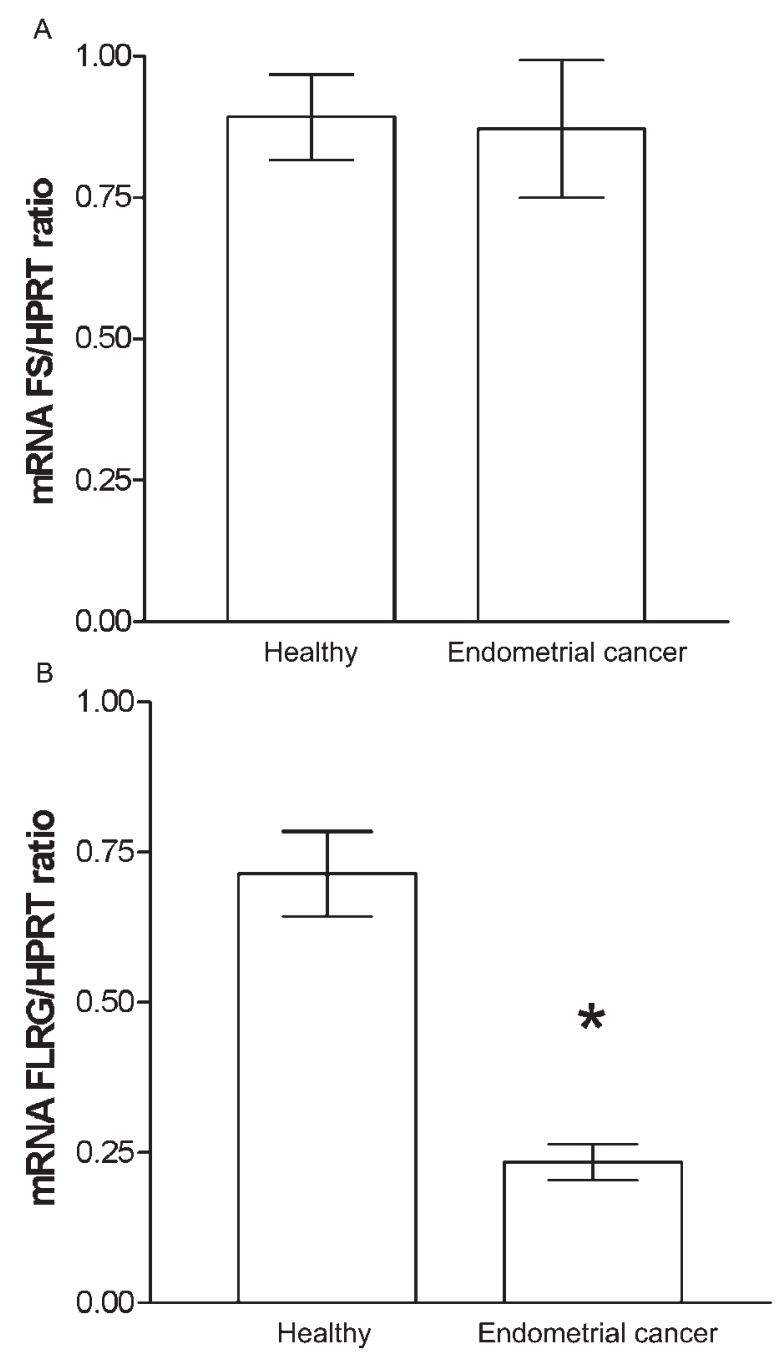

Figure 1 The charts represent the mean \pm S.E. of the ratios between (A) follistatin (FS) and HPRT mRNAs, and (B) FLRG and HPRT mRNAs. ${ }^{\star} P<0.0001$ vs healthy endometrial cells. with vessel wall and non-neoplastic glandular cells (entrapped in the same slide), which conversely were intensively stained. In some areas, tumoral cells were so devoid of FLRG staining to be considered as negative (Fig. 3A to 3E). This result was present in all the different samples of endometrial adenocarcinoma evaluated, independent of the grade of differentiation.

With respect to healthy samples, the staining intensity was found to be lower by all independent assessors (Table 1).

\section{Discussion}

In the present study we first demonstrated that human post-menopausal endometrium expresses both FLRG and follistatin mRNAs and peptides, and that they are mainly localized in glandular, stromal and endothelial cells. This localization resembles that previously reported in fertile women, thus suggesting that the localization of the two activin A binding proteins does not differ between fertile and menopausal endometrium $(22,23)$. Furthermore, in menopausal endometrium FLRG was detected not only in the cytoplasma, but also in the nucleus of all positive cells, confirming the evidence found in fertile women (23). Since the nuclear localization signal has previously been described for the activin $\beta A$-subunit precursor, and activin A has been observed in the nuclei of rat spermatogenic cells (27), we conclude that FLRG may bind activin A en route to the nucleus, or that some novel transport mechanisms may be involved in activin A signaling, both in normal and in tumoral endometrium.

In addition, FLRG immunostaining was very weak in endometrial tumoral glands, whilst it remained very intense in vascular vessels, supporting its role in tumoral angiogenesis. Because activin A modulates endothelial cell functions $(28,29)$ it is possible that there is a role for FLRG in modulating the activin A effect on vascular proliferation and angiogenesis.

The second result of the present study is that the expression of FLRG, but not of follistatin, is decreased in endometrial cancer, questioning the role played by the activin A pathway in endometrial carcinoma. In fact, we (15) and others (21) have reported that activin $A$ is over-expressed and secreted by tumoral endometrium, thus suggesting that activin A signaling may be involved in the events cascade leading to carcinogenesis. This concept is further reinforced by the fact that activin $\mathrm{A}$ is able to modulate the differentiation of both healthy (18) and tumoral (30) endometrial cells, as it stimulates stromal cells to differentiate in decidual cells, and because the loss of activin A signaling has been related to the malignant progression of an estrogen receptor-negative endometrial cancer cell line (30). 

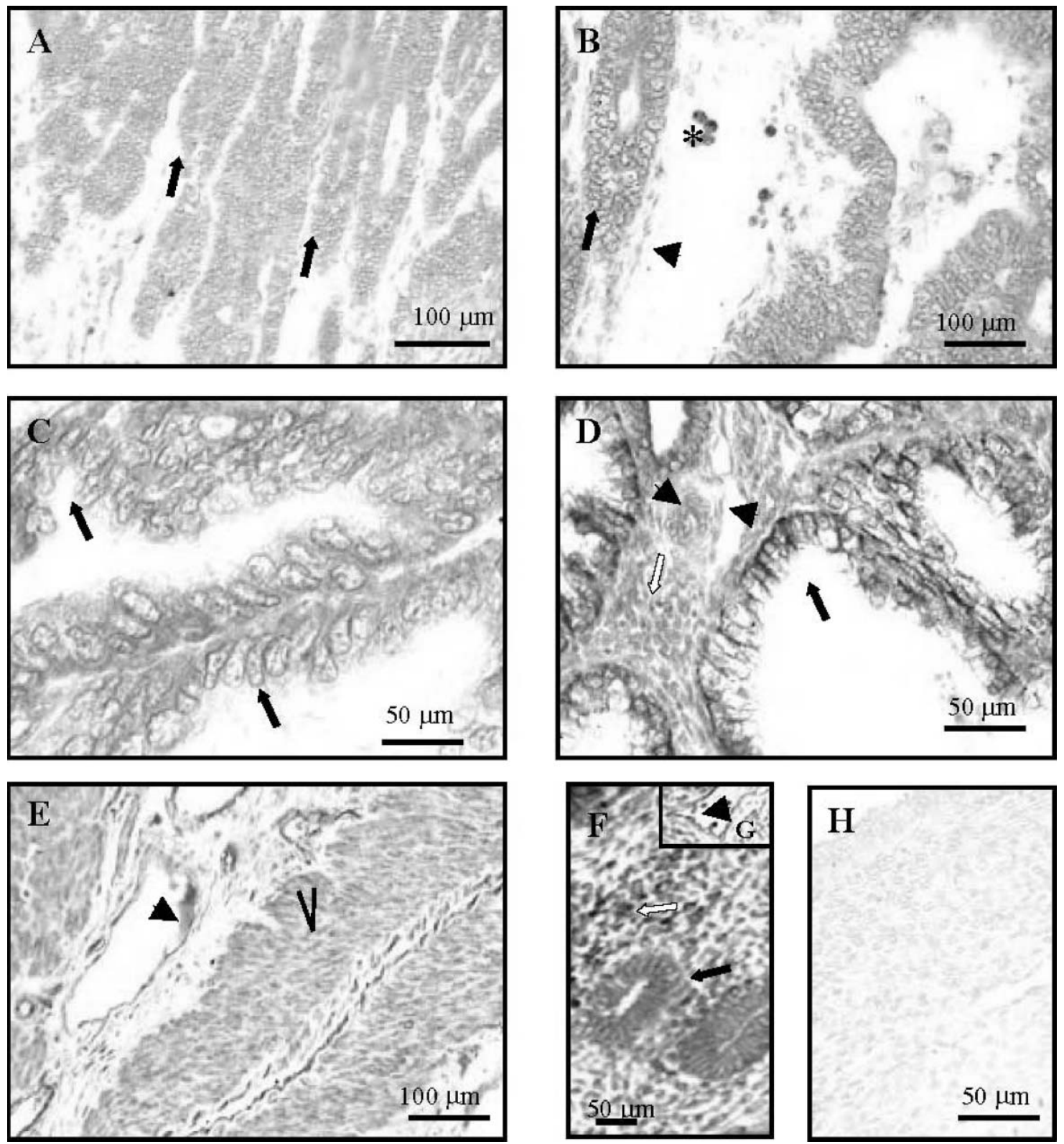

Figure 2 Follistatin immunolocalization. (A-C) Well-differentiated endometrioid adenocarcinoma showing cytoplasmic immunopositivity for follistatin (solid arrows). Endothelial cells of vessels in the stroma (arrowheads) were also positive. Inside a vein (B), circulating leucocytes $\left(^{*}\right)$ were also positive. (D, E) Neoplastic cells of poorly differentiated endometrial adenocarcinoma (E: with squamous differentiation) also showed immunopositivity both in neoplastic (solid arrow) and endothelial cells (arrowheads). The open arrow shows stromal cells. (F) Atropic post-menopausal endometrial stromal (open arrow) and epithelial cells also featured follistatin positivity. (G) Non-neoplastic endothelial cells (arrowhead). (H) Negative control.

The lack of changes in follistatin expression is also surprising, since in other tissues its expression, like that of FLRG, is up-regulated by activin A and providing a negative feed-back on activin A actions (31).

Taken together, these findings lead us to suggest that activin A signal in human endometrial cancer may be impaired through changes in local FLRG and follistatin expression. Thus, the specific misregulation of FLRG/follistatin expression in these tumors may indicate: (i) a functional separation of activin signaling based on the FLRG and follistatin expression; (ii) that a molecular component of the activin signaling pathway that is unique to the regulation of FLRG may be missing in endometrial tumors; and (iii) that the missing portion of the activin signaling pathway that fails to increase follistatin transcription is also a candidate for the lesion that fails to bring about robust activin-mediated inhibition of cell proliferation, and therefore may contribute to endometrial tumor progression. 

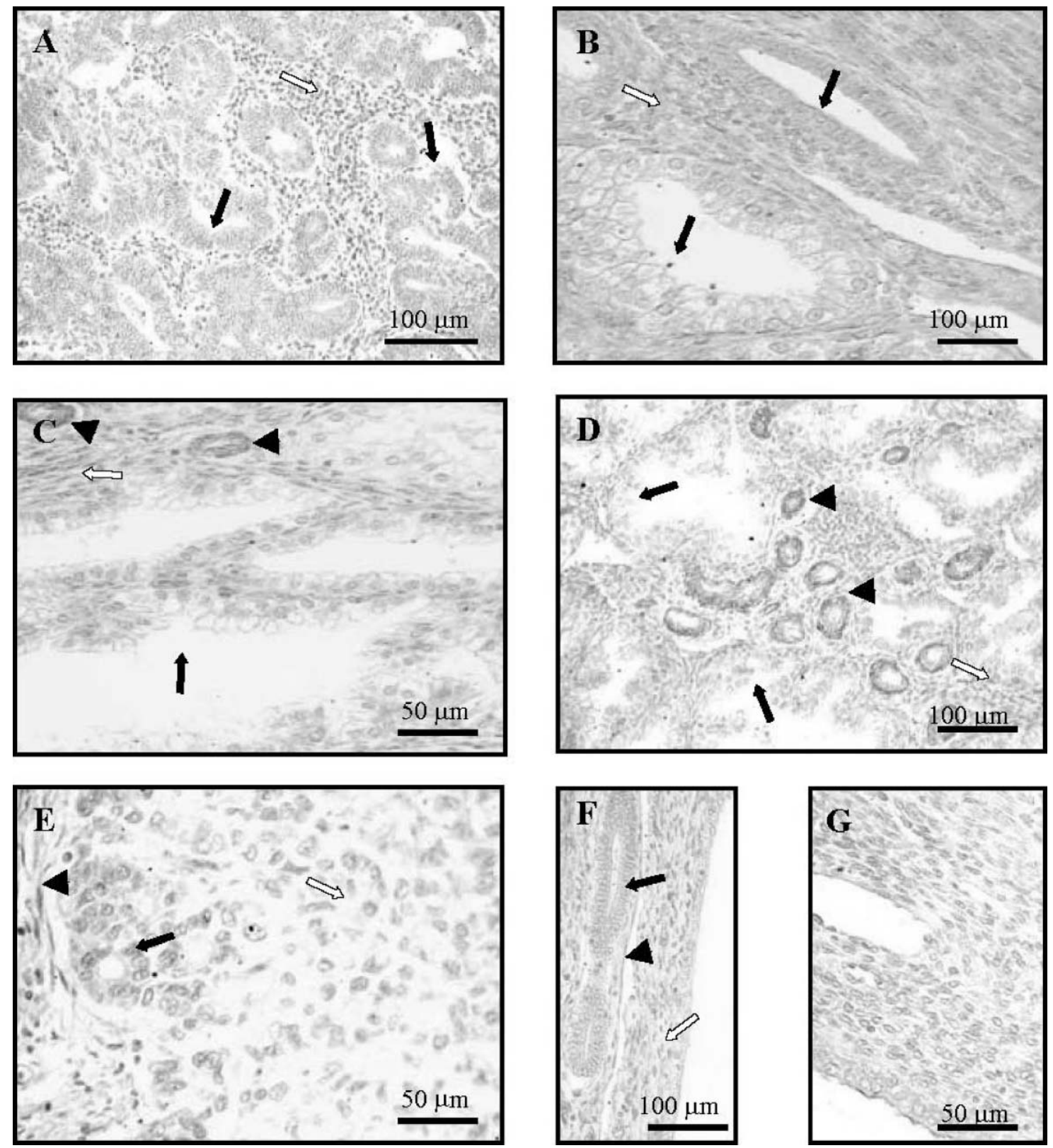

Figure 3 FLRG immunolocalization in well differentiated (A-D) and poorly differentiated (E) endometrioid adenocarcinoma. Neoplastic glands (indicated by the solid arrows) showed weaker and patchy immunoreaction. The vessel walls featured stronger immunoreactivity both in endothelial and smooth muscle cells (arrowheads). Endometrial stromal cells featured immunoreactivity restricted to the nucleus (open arrows). (F) Non-neoplastic post-menopausal endometrial glands (as shown by arrows) presented strong and consistent immunoreaction both in the cytoplasm (solid arrow) and the nucleus (open arrow). Endothelial cells (arrowhead) were also positive. (G) Negative control.

In conclusion the expression of FLRG, but not of follistatin, changes in endometrial adenocarcinoma, suggesting that the failure in a common pathway that involves the regulation of activin may be pivotal in endometrial tumor progression.

\section{References}

1 Vale W, Rivier C, Hsueh A, Campen C, Meunier H, Bicsak T, Vaughan J, Corrigan A, Bardin W, Sawchenko P et al. Chemical and biological characterization of the inhibin family of protein hormones. Recent Progress in Hormone Research $1988 \mathbf{4 4}$ $1-34$.

2 Luisi S, Florio P, Reis FM \& Petraglia F. Expression and secretion of activin A: possible physiological and clinical implications. European Journal of Endocrinology 2001145 225-236.

3 Wankell M, Kaesler S, Zhang YQ, Florence C, Werner S \& Duan R. The activin binding proteins follistatin and follistatin-related protein are differentially regulated in vitro and during cutaneous wound repair. Journal of Endocrinology 2001 171 385-395.

4 Ling N, Ying SY, Ueno N, Esch F, Denoroy L \& Guillemin R. Isolation and partial characterization of a $\mathrm{Mr} 32000$ protein 
with inhibin activity from porcine follicular fluid. PNAS $1985 \mathbf{8 2}$ $7217-7221$

5 Robertson DM, Klein R, de Vos FL, McLachlan RI, Wettenhall RE, Hearn MT, Burger HG \& de Kretser DM. The isolation of polypeptides with FSH suppressing activity from bovine follicular fluid which are structurally different to inhibin. Biochemical and Biophysical Research Communications 1987149 744-749.

6 Ueno N, Ling N, Ying SY, Esch F, Shimasaki S \& Guillemin R. Isolation and partial characterization of follistatin: a singlechain Mr 35000 monomeric protein that inhibits the release of follicle-stimulating hormone. PNAS $1987 \mathbf{8 4} 8282-8286$.

7 Nakamura T, Takio K, Eto Y, Shibai H, Titani K \& Sugino H. Activin-binding protein from rat ovary is follistatin. Science $1990247836-838$.

8 Kogawa K, Nakamura T, Sugino K, Takio K, Titani K \& Sugino H. Activin-binding protein is present in pituitary. Endocrinology 1991 128 1434-1440.

9 de Winter JP, ten Dijke P, de Vries CJ, van Achterberg TA, Sugino $\mathrm{H}$, de Waele P, Huylebroeck D, Verschueren K \& van den Eijndenvan Raaij AJ. Follistatins neutralize activin bioactivity by inhibition of activin binding to its type II receptors. Molecular and Cellular Endocrinology 1996116 105-114.

10 Hayette S, Gadoux M, Martel S, Bertrand S, Tigaud I, Magaud JP \& Rimokh R. FLRG (follistatin-related gene), a new target of chromosomal rearrangement in malignant blood disorders. Oncogene $1998162949-2954$.

11 Tsuchida K, Arai KY, Kuramoto Y, Yamakawa N, Hasegawa Y \& Sugino H. Identification and characterization of a novel follistatin-like protein as a binding protein for the TGF-beta family. Journal of Biological Chemistry 2000275 40788-40796.

12 Sidis Y, Schneyer AL, Sluss PM, Johnson LN \& Keutmann HT. Follistatin: essential role for the N-terminal domain in activin binding and neutralization. Journal of Biological Chemistry 2001 276 17718-17726.

13 Tortoriello DV, Sidis Y, Holtzman DA, Holmes WE \& Schneyer AL. Human follistatin-related protein: a structural homologue of follistatin with nuclear localization. Endocrinology $2001 \mathbf{1 4 2}$ 3426-3434.

14 Maguer-Satta V, Bartholin L, Jeanpierre S, Gadoux M, Bertrand S, Martel S, Magaud JP \& Rimokh R. Expression of FLRG, a novel activin A ligand, is regulated by TGF-beta and during hematopoiesis. Experimental Hematology $200129301-308$.

15 Petraglia F, Florio P, Luisi S, Gallo R, Gadducci A, Vigano P, Di Blasio AM, Genazzani AR \& Vale W. Expression and secretion of inhibin and activin in normal and neoplastic uterine tissues. High levels of serum activin A in women with endometrial and cervical carcinoma. Journal of Clinical Endocrinology and Metabolism 199883 1194-1200.

16 Florio P, Luisi S, Vigano P, Busacca M, Fadalti M, Genazzani AR \& Petraglia F. Healthy women and patients with endometriosis show high concentrations of inhibin A, inhibin B, and activin A in peritoneal fluid throughout the menstrual cycle. Human Reproduction $1998132606-2611$.

17 Leung PH, Salamonsen LA \& Findlay JK. Immunolocalization of inhibin and activin subunits in human endometrium across the menstrual cycle. Human Reproduction 199813 3469-3477.

18 Jones RL, Salamonsen LA, Critchley HO, Rogers PA, Affandi B \& Findlay JK. Inhibin and activin subunits are differentially expressed in endometrial cells and leukocytes during the menstrual cycle, in early pregnancy and in women using progestin-only contraception. Molecular Human Reproduction 20006 1107-1117.

19 Reis FM, Di Blasio AM, Florio P, Ambrosini G, Di Loreto C \& Petraglia F. Evidence for local production of inhibin A and activin A in patients with ovarian endometriosis. Fertility and Sterility $200175367-373$.

20 Otani T, Minami S, Kokawa K, Shikone T, Yamoto M \& Nakano R. Immunohistochemical localization of activin A in human endometrial tissues during the menstrual cycle and in early pregnancy. Obstetrics and Gynecology 199891 685-692.

21 Otani T, Minami S, Yamoto M \& Umesaki N. Production of activin $\mathrm{A}$ in hyperplasia and adenocarcinoma of the human endometrium. Gynecologic Oncology 200183 31-38.

22 Florio P, Severi FM, Luisi S, Ciarmela P, Calonaci G, Cobellis L \& Petraglia F. Endometrial expression and secretion of activin A, but not follistatin, increase in the secretory phase of the menstrual cycle. Journal of the Society for Gynecologic Investigation $200310237-243$.

23 Florio P, Ciarmela P, Toti P, Maguer-Satta V, Rimokh R, Buonocore G, Rossi M \& Petraglia F. Human endometrium and decidua express follistatin-related gene (FLRG) mRNA and peptide. Molecular and Cellular Endocrinology 2004218 129-135.

24 Vigano P, Somigliana E, Mangioni S, Vignali M, Vignali M \& Di Blasio AM. Expression of interleukin-10 and its receptor is upregulated in early pregnant versus cycling human endometrium. Journal of Clinical Endocrinology and Metabolism $2002 \mathbf{8 7}$ $5730-5736$.

25 Altschul SF, Madden TL, Schaffer AA, Zhang J, Zhang Z, Miller W et al. Gapped BLAST and PSI-BLAST: a new generation of protein database search programs. Nucleic Acids Research 199725 3389-3402.

26 Bilezikjian LM, Corrigan AZ, Vaughan JM \& Vale WM. Activin-A regulates follistatin secretion from cultured rat anterior pituitary cells. Endocrinology $19931332554-2560$.

27 Blauer M, Husgafvel S, Syvala H, Tuohimaa P \& Ylikomi T. Identification of a nuclear localization signal in activin/inhibin betaA subunit; intranuclear betaA in rat spermatogenic cells. Biology of Reproduction $1999 \mathbf{6 0} 588-593$.

28 Kozian DH, Ziche M \& Augustin HG. The activin-binding protein follistatin regulates autocrine endothelial cell activity and induces angiogenesis. Laboratory Investigations 199776 267-276.

29 McCarthy SA \& Bicknell R. Inhibition of vascular endothelial cell growth by activin-A. Journal of Biological Chemistry 1993268 23066-23071.

30 Di Simone N, Schneyer AL, Caliandro D, Castellani R \& Caruso A. Regulation of endometrial adenocarcinoma cell proliferation by activin-A and its modulation by 17 beta-estradiol. Molecular and Cellular Endocrinology 2002192 187-195.

31 Bartholin L, Maguer-Satta V, Hayette S, Martel S, Gadoux M, Corbo L, Magaud JP \& Rimokh R. Transcription activation of FLRG and follistatin by activin A, through Smad proteins, participates in a negative feedback loop to modulate activin A function. Oncogene $2002212227-2235$.

Received 12 January 2004

Accepted 8 April 2004 